\title{
Slaughter yield and dietary value of wild and cultured vendace (Coregonus albula)
}

\author{
Zdzisław Zakęś, Renata Pietrzak-Fiećko, Mirosław Szczepkowski, \\ Monika Modzelewska-Kapituła
}

Received - 17 September 2019/Accepted - 20 May 2020. Published online: 30 June 2020; @Inland Fisheries Institute in Olsztyn, Poland Citation: Zakęś Z., Pietrzak-Fiećko R., Szczepkowski M., Modzelewska-Kapituła M. 2020 - Slaughter yield and dietary value of wild and cultured vendace (Coregonus albula) - Fish. Aquat. Life 28: 91-98

\begin{abstract}
This study focused on comparing slaughter yield, proximate composition, and fatty acid profiles of meat from wild vendace, Coregonus albula L. caught in natural conditions (lakes; group W) and from cultured vendace reared on formulated feed in recirculating systems (group C). The slaughter yield of gutted vendace (group C) was approximately $2 \%$ higher that the value determined in group $\mathrm{W}(\mathrm{P} \leq 0.05)$. Carcasses of cultured fish contained 2.5 times more fat in comparison to fish from group W (11.12 vs $4.86 \%$ ), which was compensated for by water content. No differences in protein content were noted among groups $(\mathrm{P}>0.05)$. The relative combined share of monounsaturated fatty acids (MUFA) in carcasses of fish from group $\mathrm{C}$ were significantly higher (49.98 vs $31.53 \%$ of total fatty acids
\end{abstract}

\section{Z. Zakęś [ ["]]}

Department of Aquaculture, Stanisław Sakowicz Inland Fisheries Institute, Olsztyn, ul. Oczapowskiego 10, 10-719 Olsztyn, Poland Tel.: +48 89 5240171; Fax: +48 895240505 ;

e-mail: z.zakes@infish.com.pl

R. Pietrzak-Fiećko

Department of Commodities and Food Analysis, Faculty of Food

Sciences, University of Warmia and Mazury in Olsztyn, Poland

M. Szczepkowski

Department of Sturgeon Fish Breeding, Stanisław Sakowicz Inland

Fisheries Institute, Olsztyn, Poland

M. Modzelewska-Kapituła

Department of Meat Technology and Chemistry, Faculty of Food

Sciences, University of Warmia and Mazury in Olsztyn, Poland
(tFA)); however, the share of polyunsaturated fatty acids (PUFA), including n-3 PUFA, was lower at 18.55 vs $24.71 \%$ tFA and 8.36 vs $14.89 \%$ tFA ( $\mathrm{P} \leq 0.05)$, respectively. As a result of these lipid content values, the levels of the eicosapentaenoic (EPA; 20:5n-3) and docosahexaenoic (DHA; 22:6n-3) acids and n-3 PUFA and PUFA, expressed in mg $100 \mathrm{~g}^{-1}$ carcass, in cultured vendace carcasses were significantly higher than those in the meat of wild vendace.

Keywords: fatty acids, proximate composition, slaughter yield, vendace

\section{Introduction}

Excessive exploitation of natural resources by fisheries coupled with environmental pollution and water eutrophication have caused substantial decreases in harvests of aquatic organisms (FAO 2019a). This fact and increasing demand for fish and sea food provide the impetus for the concerted development of marine and freshwater aquaculture (FAO 2019b). Species that have high environmental requirements are particularly sensitive to environmental pollution. These include salmonids, one of which is vendace (Coregonus albula), a species that inhabits the fresh, cool waters of the northern hemisphere (Brylińska 2000). The vendace population

\footnotetext{
(c) Copyright by Stanisław Sakowicz Inland Fisheries Institute in Olsztyn.

(C) 2020 Author(s). This is an open access article licensed under the Creative Commons Attribution-NonCommercial-NoDerivs License

(http://creativecommons.org/licenses/by-nc-nd/3.0/).
} 
abundance in the waters of northern Europe has decreased significantly, which is primarily because of water pollution and climate change (Elliott and Bell 2011).

This species is of high culinary value and is in great demand in areas where is occurs naturally (Setälä 1999). Deficits in its harvest provided the impetus to undertake research with the aim of developing methods for its active conservation through restocking programs (Wziątek et al. 2009). Fish culture in recirculating aquaculture systems (RAS) has developed dynamically in the past few years (Martins et al. 2010). Technologies have been developed to produce both restocking material and commercial-sized fishes of new species to aquaculture (Badiola et al. 2012). Preliminary pilot studies have indicated that vendace can also be produced in RAS (Szczepkowska et al. 2014).

Fish culture in RAS is based on high-energy formulated feeds containing fish meal and oils or vegetable oils (Watanabe 2002). It is known that diet has a significant impact on the proximate composition, including the fatty acid (FA) profile, of fish bodies (Steffens 1997, Lie 2001, Cejas et al. 2004, Steffens and Wirth 2005, Jankowska et al. 2010). From the viewpoint of the potential consumer, it seems important to determine the impact this type of culture has on the slaughter yield and nutritional value. This is all the more important, since, to the best of the present authors' knowledge, this paper is the first to present these types of results regarding this species. The aim of the present study was to determine the slaughter yield, proximate composition, and fatty acid profile of vendace culture in RAS on formulated feed and wild specimens of a similar body weight that fed on natural feed and were caught in a natural lake.

\section{Material and methods}

\section{Fish origin}

Vendace were cultured in RAS at the Department of Sturgeon Fish Breeding, Inland Fisheries Institute in Olsztyn (IFI Olsztyn, Poland). Study material was obtained through the artificial reproduction of vendace obtained from Lake Mamry (Masurian Lake District, northeastern Poland). The fish were cultured in a RAS with a volume of $70 \mathrm{~m}^{3}$ that was equipped with square tanks made of an artificial material with a working volume of $1 \mathrm{~m}^{3}$ (Szczepkowska et al. 2014). The initial stocking density of each tank (3 tanks) was 1,000 individuals. From day 105 of culture, the fish stock was reduced leaving 400 randomly chosen fish in each tank.

During culture until 304 days post-hatch (DPH), the fish were fed Nutra commercial feed (Skretting, France). These were composed of $52.0 \%$ protein, $20.0 \%$ lipids, $8.5 \%$ carbohydrate, $11.0 \%$ ash, and the digestible energy was $19.9 \mathrm{MJ} \mathrm{kg}^{-1}$ (manufacturer's data). For the subsequent 12 months, the fish were fed E-Stella 1P feed (Skretting, Norway) composed of $47.0 \%$ protein, $14.0 \%$ lipids, $21.0 \%$ carbohydrate, $7.5 \%$ ash, and $2.9 \%$ fiber (granulate size $-2.5 \mathrm{~mm}$ ). The feed was delivered using an automatic band feeder (FIAP, Germany). The fish were fed for $12 \mathrm{~h} \mathrm{~d}^{-1}$ (19:00-07:00). The daily feed ration was $0.5 \%$ of the stock biomass.

The mean water temperature during culture was $18.0^{\circ} \mathrm{C}$ (range $13.0-21.5^{\circ} \mathrm{C}$ ). Oxygen concentration at the culture tank outflows was higher than $6.2 \mathrm{mg}$ $\mathrm{O}_{2} \mathrm{l}^{-1}$, and the water $\mathrm{pH}$ range was 7.20-7.67. The level of total ammonia nitrogen $\left(\mathrm{TAN}=\mathrm{NH}_{4}{ }^{+}-\mathrm{N}+\right.$ $\mathrm{NH}_{3}-\mathrm{N}$ ) at the tanks outflows did not exceed $0.35 \mathrm{mg}$ TAN ${ }^{-1}$, and the nitrite content $\left(\mathrm{NO}_{2}-\mathrm{N}\right)$ did not exceed $0.25 \mathrm{mg} \mathrm{NO} \mathrm{NO}_{2}-\mathrm{N} \mathrm{l}^{-1}$. The tanks were cleaned daily of excrement and unconsumed feed and fish mortalities were recorded.

In September, 12 specimens were collected from the culture tanks and from the wild. The wild fish were caught in Lake Harsz (Masurian Lake District, northeastern Poland) using gillnets with mesh size of $22 \mathrm{~mm}$. The fish were selected so that each group comprised the same number of males and females ( 6 specimens each) and the mean body weights were similar. The cultured vendace (group C) weighed 73 $\mathrm{g}$, and the wild specimens (group W) weighed $69 \mathrm{~g}$ (age of 2+; determined from scale readings; Brylińska 2000). Immediately following capture, the fish were cooled and held on ice for $24 \mathrm{~h}$. Then they 
were gutted and headed. All of the parts obtained, i.e., the gutted fish, the combined viscera (visceral fat, liver, gonads), liver, gonads, gutted and headed fish, head and pectoral fins, were weighed $( \pm 0.1 \mathrm{~g})$ and the percentage of total body weight (BW) of these parts was calculated. The ground (3 $\mathrm{mm}$ mesh screen openings) gutted and headed fish was the material used to determine the proximate composition and for the analysis of the fatty acid composition.

\section{Determining proximate composition}

Moisture content was determined by drying samples at a temperature of $105^{\circ} \mathrm{C}$ to a constant weight. Total protein was determined with the Kjeldahl method using a multiplier of 6.25. The lipid content was determined with the Soxhlet method using a petroleum ether solvent. The total content of mineral components was determined by mineralizing the samples at temperatures of $550-600^{\circ} \mathrm{C}$ (AOAC 1995). The energy value was calculated using individual caloric or energy equivalents, i.e., $4.0 \mathrm{kcal} \mathrm{g}^{-1}$ protein and $9.0 \mathrm{kcal} \mathrm{g}^{-1}$ lipid or $24 \mathrm{~kJ}$ $\mathrm{g}^{-1}$ protein and $39 \mathrm{~kJ} \mathrm{~g}^{-1}$ lipid (Cichoń 2003).

\section{Determining fatty acid composition}

Analyses of fatty acids was performed after separating lipids from the formulated feed and from the vendace carcasses with cold extraction with a mixture of chloroform/methanol $(2: 1, \mathrm{v} / \mathrm{v})$. The procedure used was identical to that used in previous investigations (Jankowska et al. 2006).

\section{Statistical analysis}

The results were analyzed statistically with Statistica (StatSoft Inc., USA). Data normality was verified using the Shapiro-Wilk test and the homogeneity of variance was verified with Levene's test. Means were compared with one-way analysis of variance (ANOVA). When statistically significant differences between experimental groups were confirmed $(\mathrm{P} \leq 0.05)$, further statistical analysis was performed using the Scheffe test. Prior to statistical analyses, all values expressed in percentages were transformed using the $\arcsin$ function.

\section{Results and discussion}

The slaughter yield of gutted vendace (group C) was about 2\% BW higher than that confirmed in the wild vendace (group W). This is linked mainly with the higher gonad weight in the wild fish (Table 1). While differences between groups with regard to headed

Table 1

Slaughter yield of wild (group W) and cultured (group C) vendace. For explanation see Materials and methods

\begin{tabular}{|c|c|c|c|c|}
\hline & \multirow[b]{2}{*}{ Units } & \multicolumn{2}{|l|}{ Fish groups } & \multirow[b]{2}{*}{$\mathrm{P}$} \\
\hline & & group $W(n=12)$ & group $C(n=12)$ & \\
\hline Body weight (b.w.) & $\mathrm{g}$ & $68.75 \pm 13.95$ & $73.30 \pm 16.37$ & ns \\
\hline \multirow{2}{*}{ Gutted fish weight } & $\mathrm{g}$ & $60.18 \pm 10.53$ & $66.42 \pm 13.85$ & ns \\
\hline & \% b.w. & $88.02 \pm 3.02$ & $90.93 \pm 2.71$ & $*$ \\
\hline \multirow[t]{2}{*}{ Gonads weight } & $\mathrm{g}$ & $4.02 \pm 2.68$ & $1.89 \pm 1.84$ & $*$ \\
\hline & \% b.w. & $5.34 \pm 2.94$ & $2.27 \pm 1.84$ & $* *$ \\
\hline \multirow{2}{*}{ Liver weight } & $\mathrm{g}$ & $0.77 \pm 0.29$ & $0.74 \pm 0.29$ & ns \\
\hline & \% b.w. & $1.09 \pm 0.25$ & $0.98 \pm 0.17$ & ns \\
\hline \multirow{2}{*}{ Viscera weight } & $\mathrm{g}$ & $7.73 \pm 3.34$ & $5.42 \pm 2.48$ & ns \\
\hline & \% b.w. & $10.76 \pm 2.88$ & $7.16 \pm 2.07$ & $* *$ \\
\hline \multirow[t]{2}{*}{ Head weight } & $\mathrm{g}$ & $10.15 \pm 1.50$ & $14.17 \pm 2.65$ & $* * *$ \\
\hline & \% b.w. & $14.94 \pm 1.29$ & $19.52 \pm 1.44$ & $* * *$ \\
\hline \multirow[t]{2}{*}{ Carcass weight (without head and viscera) } & $\mathrm{g}$ & $49.72 \pm 9.29$ & $52.06 \pm 11.25$ & ns \\
\hline & \% b.w. & $72.56 \pm 2.12$ & $71.17 \pm 2.07$ & ns \\
\hline \multirow[t]{2}{*}{ Loss } & $\mathrm{g}$ & $0.91 \pm 0.39$ & $1.45 \pm 0.75$ & ns \\
\hline & \% b.w. & $1.79 \pm 0.78$ & $1.91 \pm 0.78$ & ns \\
\hline
\end{tabular}

Mean values $\pm \mathrm{SD}$; $\mathrm{ns}$ - differences not statistically significant $\mathrm{P}>0.05 ;{ }^{*} \mathrm{P} \leq 0.05 ;{ }^{*} \mathrm{P} \leq 0.01 ;{ }^{*}{ }^{*} \mathrm{P} \leq 0.001$ 
and gutted fish were detected, they were statistically insignificant ( $\mathrm{P}>0.05$; Table 1$)$. The slaughter yields of this species in gutted (88-91\% BW) and gutted and headed $(71-73 \%$ BW) fish were high, and the values were more advantages than in other species of fish (Jankowska et al. 2003, 2007b). This fact stems from the small head of this species in comparison to those of other fishes (Brylińska 2000). In the current study, only two stages of vendace processing were analyzed (fillet slaughter yield was not considered), because this species is only traded and consumed as gutted fish or gutted and headed fish (e.g., smoked, fried, marinated) (Z. Zakęś, unpublished materials). Feeding fish intensively with high-energy feeds often results in higher viscera weight, which is usually linked with the deposition of visceral fat in the abdominal cavity. This trait can lower the slaughter yield of this type of individual, for example, in comparison with wild fish that feed on natural food (Mairesse et al. 2005, Jankowska et al. 2006). Formulated feed does not always lead to changes in the slaughter yield of a given species. Significant differences in the values of this parameter were not calculated for cultured and wild pikeperch, Sander lucioperca (L.) and for wels catfish, Silurus glanis L. (Jankowska et al. 2003, 2007b). Thus, the impact of feeding fish formulated feed, expressed as changes in slaughter yield, can be considered to be a trait specific to species.

The lipid content of vendace from group $\mathrm{C}$ was $6.3 \%$ higher (more than twofold) than that of the wild fish (Table 2). The caloric value of cultured vendace was about 50\% higher (174 vs $117 \mathrm{kcal} 100 \mathrm{~g}^{-1}$ ) (Table 2). Data from the literature indicates that the lipid content of wild vendace is fairly variable and ranges from 0.5 to $4.9 \%$ (Muje et al. 1989, Linko et al. 1992, Woźniak et al. 2013). From a nutritional perspective, vendace meat is classified as lean $(<2 \%$ lipid $)$ or moderate-fat (4-8\% lipid; Macrae et al. 1993). Lipid content is determined by the feeding conditions in a given lake, seasonal fluctuations in food availability (zooplankton), and the sexual maturity stage of the fish (annual gonad development cycle) (Linko et al. 1992). The lipid content of the vendace from group $\mathrm{W}$ was in the upper range of the figure cited above (4.86\%). This is certainly linked with the prevailing feeding conditions in the lake and also with the fish being caught in September, which is when the period of intense somatic growth in vendace finishes (Linko et al. 1992). Muje et al. (1989) noted, for example, that in vendace occurring in a Finnish lake the muscle lipid content increases from about $1 \%$ at the beginning of June to about 2.5\% in August. The lipid content in vendace from group $\mathrm{C}$ was decidedly higher and reached values in excess of $11 \%$ (in comparison to the wild fish this was an increase of more than 6\%). This is one of the highest increases in the lipid content observed in fish (cultured vs wild). To date, mainly predatory fish species have been studied, and the reported lipid content in fillets of individuals fed formulated feed is in the range of 1-5\% (Xu et al. 2001, Mairesse et al. 2005, Jankowska et al. 2006, 2007a, 2007b, 2010). Feeding vendace feed

Table 2

Proximate composition (\% of wet weight) of gutted and headed wild (group W) and cultured (group C) vendace. For explanation see Materials and methods

\begin{tabular}{|c|c|c|c|}
\hline & \multicolumn{2}{|l|}{ Fish groups } & \multirow{2}{*}{$\mathrm{P}$} \\
\hline & group $W(n=12)$ & group $C(n=12)$ & \\
\hline Water & $75.24 \pm 0.84$ & $68.80 \pm 1.57$ & $* *$ \\
\hline Fat & $4.86 \pm 0.78$ & $11.12 \pm 1.32$ & $* *$ \\
\hline Protein & $18.30 \pm 0.93$ & $18.23 \pm 1.43$ & ns \\
\hline Mineral components & $1.49 \pm 0.12$ & $1.65 \pm 0.18$ & $*$ \\
\hline Caloric value (kcal $100 \mathrm{~g}^{-1}$ ) & $116.98 \pm 5.77$ & $173.86 \pm 11.86$ & $* * *$ \\
\hline Energetic value (kJ $\left.100 \mathrm{~g}^{-1}\right)$ & $628.98 \pm 25.40$ & $871.36 \pm 54.49$ & $* * *$ \\
\hline
\end{tabular}

Mean values $\pm \mathrm{SD}$; $\mathrm{ns}$ - differences not statistically significant $\mathrm{P}>0.05 ;{ }^{*} \mathrm{P} \leq 0.05 ;{ }^{*} \mathrm{P} \leq 0.01 ;{ }^{*}{ }^{*} \mathrm{P} \leq 0.001$ 
with high contents of lipids and carbohydrates resulted in a significant increase in the lipid content of the carcasses. Excess energy supplied by the diet is stored as triglycerides in the muscles and/or it is deposited in other fat tissues of the fish, i.e., as visceral fat, and also in the liver and gonads (Jobling 2001). The weight of the viscera was similar in the cultured and wild vendace, so it appears that in this species excess fat reserves were deposited mainly in the muscles.

The qualitative composition of the fatty acids (FA) in cultured and wild vendace were similar. Thirty FA were identified in each group of fish. Significant differences were confirmed in the quantitative composition of the FA. The relative quantity of FA (\% of total fatty acids (tFA)) did not differ significantly $(\mathrm{P}>0.05)$ between cultured and wild vendace in only five of the $30 \mathrm{FA}$ confirmed. These were the following acids: $16: 1 ; 20: 3 n-6 ; 20: 5 n-3 ; 22: 1 n-9$; 22:5n-3. Particularly large differences were noted in the content of oleic acid (C18:1cis 9), the contents of which in cultured vendace were about $17 \% \mathrm{tFA}$ higher (Table 3). In the case of FA that are particularly significant from a dietary perspective, i.e., eicosapentaenoic acid (EPA; 20:5n-3) and docosahexaenoic acid (DHA; 22:6n-3), the differences were not as pronounced (Table 3). Differences in the percentage share of individual FA resulted in different fatty acid profiles, i.e., saturated fatty acids (SFA), unsaturated fatty acids (UFA), monounsaturated fatty acids (MUFA), and polyunsaturated fatty acids (PUFA) (Table 3). MUFA in fish from group C comprised nearly $50 \%$ of the $\mathrm{tFA}$, while the content of PUFA in these individuals was over $6 \%$

Table 3

Content of selected fatty acids (\% total fatty acids) in formulated feed and in carcasses of wild (group W) and cultured vendace (group C)

\begin{tabular}{|c|c|c|c|c|}
\hline & \multirow[b]{2}{*}{ Formulated feed } & \multicolumn{2}{|l|}{ Fish groups } & \multirow[b]{2}{*}{$\mathrm{P}$} \\
\hline & & group W $(n=12)$ & group $C(n=12)$ & \\
\hline $16: 00$ & 19.92 & $25.22 \pm 1.14$ & $20.60 \pm 1.27$ & $* * *$ \\
\hline 18:1cis9 & 27.58 & $14.58 \pm 0.95$ & $31.70 \pm 1.18$ & $* * *$ \\
\hline $18: 2 n-6$ & 10.12 & $6.15 \pm 0.37$ & $8.97 \pm 0.46$ & $* * *$ \\
\hline $18: 3 n-3$ & 1.45 & $3.90 \pm 0.41$ & $1.19 \pm 0.14$ & $* * *$ \\
\hline $20: 4 n-6$ & 0.72 & $1.74 \pm 0.25$ & $0.36 \pm 0.06$ & $* * *$ \\
\hline $20: 5 n-3$ & 7.18 & $2.68 \pm 0.54$ & $2.69 \pm 0.67$ & ns \\
\hline $22: 6 n-3$ & 1.89 & $3.37 \pm 0.85$ & $2.41 \pm 0.84$ & $*$ \\
\hline $\mathrm{SFA}^{1}$ & 30.59 & $43.75 \pm 2.00$ & $31.47 \pm 1.86$ & ** \\
\hline $\mathrm{UFA}^{2}$ & 69.41 & $56.25 \pm 2.00$ & $68.53 \pm 1.86$ & $* *$ \\
\hline MUFA $^{3}$ & 44.85 & $31.53 \pm 1.39$ & $49.98 \pm 1.49$ & $* *$ \\
\hline $\mathrm{PUFA}^{4}$ & 24.56 & $24.72 \pm 2.92$ & $18.55 \pm 2.26$ & $* *$ \\
\hline n-3 PUFA ${ }^{5}$ & 12.66 & $14.89 \pm 2.43$ & $8.36 \pm 1.92$ & $* *$ \\
\hline n-6 PUFA ${ }^{6}$ & 11.76 & $9.12 \pm 0.64$ & $9.80 \pm 0.51$ & * \\
\hline$n-3 / n-6$ & 1.08 & $1.63 \pm 0,21$ & $0.85 \pm 0.17$ & $* *$ \\
\hline $\begin{array}{l}{ }^{1} \text { SFA - satu } \\
{ }^{2} \text { UFA - unsa } \\
20: 2,20: 3 n- \\
{ }^{3} \text { MUFA - m } \\
{ }^{4} \text { PUFA - pol } \\
22: 5 n-6,22: \\
{ }^{5} \text { n-3 PUFA - } \\
{ }^{6} \text { n-6 PUFA - }\end{array}$ & $\begin{array}{l}\text { acids, } \Sigma 12: 0,14: 0 \\
\text { tty acids, } \Sigma 14: 1,16 \\
6,20: 3 n-3,20: 4 n-3 \\
\text { urated fatty acids, } \Sigma \\
\text { ted fatty acids, } \Sigma 18 \\
6 n-3 . \\
\text { ly PUFA, } \Sigma 18: 3 n-3 \\
\text { ly PUFA, } \Sigma 18: 2 n-6\end{array}$ & $\begin{array}{l}16: 0,17: 0,18: 0,20 \\
1,18: 1 \text { cis } 9,18: 1 \text { cis } 1 \\
-3,22: 1 n-11,22: 1 n \\
6: 1,17: 1,18: 1 \text { cis } 9, \\
8: 3 n-6,18: 3 n-3,18 \\
-3,20: 3 n-3,20: 4 n-? \\
-6,20: 3 n-6,20: 4 n-6 \\
\text { ly significant } P>0.0\end{array}$ & $\begin{array}{l}n-6,18: 3 n-6,18: 3 n \\
n-6,22: 5 n-3,22: 6 \\
11,20: 1 n-9,20: 1 n \\
0: 2,20: 3 n-6,20: 41 \\
-3,22: 5 n-3,22: 6 n \\
-6 . \\
=0.05 ; * * P \leq 0.01 ;\end{array}$ & $\begin{array}{l}: 1 n-9,20: 1 n-7, \\
2: 1 n-9 . \\
: 4 n-3,20: 5 n-3,\end{array}$ \\
\hline
\end{tabular}


tFA lower $(\mathrm{P} \leq 0.01$; Table 3$)$. Cultured vendace contained less n-3 PUFA (8.36 vs $14.89 \%$ tFA) and more n-6 PUFA (9.80 vs $9.12 \% \mathrm{tFA})$. This was reflected in the values of the $n-3 / n-6$ ratio, for which a higher value was confirmed in wild fish $(\mathrm{P} \leq 0.01$; Table 3).

Comparisons of the contents of individual PUFA and groups of these acids ( $n-3$ and n-6 PUFA) in 100 $\mathrm{g}$ fish carcass from group $\mathrm{C}$ and $\mathrm{W}$ revealed large differences (Fig. 1). The content of linoleic acid (18:2n-6) in cultured fish was more than threefold higher (699.5 vs $209.5 \mathrm{mg} 100 \mathrm{~g}^{-1}$; $\mathrm{P} \leq 0.001$ ), while that of $\alpha$-linolenic acid (18:3n-3) was lower (93.07 vs $\left.133.79 \mathrm{mg} 100 \mathrm{~g}^{-1} ; \mathrm{P} \leq 0.001\right)$. The level of arachidonic acid (AA) was higher in wild fish (59.14 vs $28.26 \mathrm{mg} 100 \mathrm{~g}^{-1}$; $\left.\mathrm{P} \leq 0.001\right)$. The combined content of n-3 PUFA, n-6 PUFA, PUFA and EPA and DHA was significantly higher in cultured vendace (Fig. 1).

Higher MUFA and lower PUFA contents in the meat of freshwater cultured fish in comparison to wild fish is often observed (see Mairesse et al. 2005, Jankowska et al. 2006, 2010). Higher MUFA values in cultured fish are mainly linked to higher contents of oleic acid (18:1cis9). It must be emphasized that the contents of 18:1cis9 in cultured vendace was

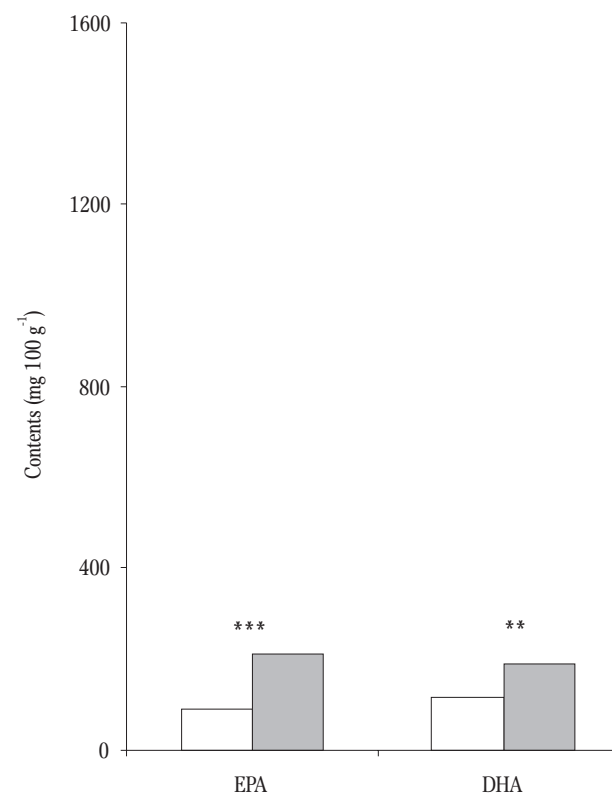

lower than that in the formulated feed. Thus, it can be concluded that this FA was a source of metabolic energy. It is also noteworthy that the content of DHA noted in cultured vendace was also higher than that in the formulated feed. This can be associated with the selective retention of this FA or the metabolic conversion of fatty acids from the n-3 family with shorter carbon chains and fewer double bonds into longer-chained, more unsaturated derivatives. The phenomenon of $\mathrm{n}-3$ fatty acid bioconversion has been observed in other freshwater fish species (see Xu et al. 2001, Jankowska et al. 2003, 2010). However, it is important to emphasize that the vendace from group $\mathrm{C}$ had lower contents of n-3 PUFA and a less advantageous $n-3 / n-6$ ratio in comparison to the fish from group $\mathrm{W}$ and also in comparison to that noted in the formulated feed.

The decidedly higher content of AA in wild vendace is noteworthy. Ahlgren et al. (1999) reported higher contents of AA in wild grayling (Thymallus thymallus), while Cejas et al. (2004) did so for white seabream (Diplodus sargus). The vendace diet comprises primarily zooplankton (Cladocera, Copepoda) (Linko et al. 1992). Freshwater invertebrates contain more AA than formulated feed (Bell et al. 1994). Unfortunately, data regarding the fatty acid profiles of

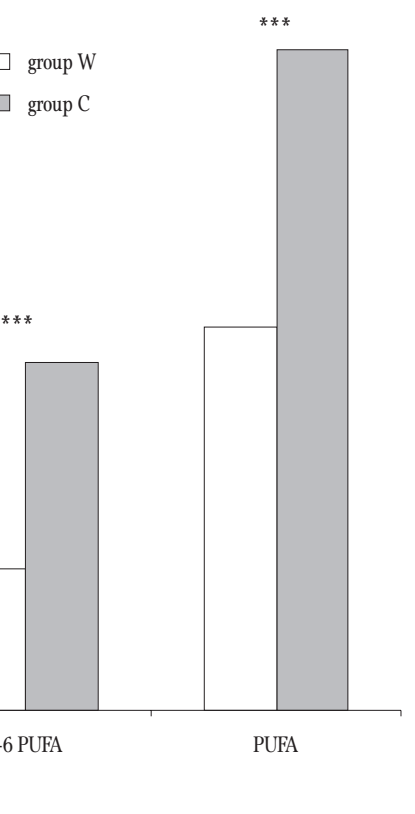

Figure 1. Content of selected fatty acids (mg $100 \mathrm{~g}^{-1}$ carcass wild (group W) and cultured vendace (group C)) (mean values \pm SD; $\left.{ }^{*} \mathrm{P} \leq 0.05 ;{ }^{*} \mathrm{P} \leq 0.01 ;{ }^{*} * \mathrm{P} \leq 0.001\right)$. 
the natural food of wild vendace are lacking, but the results obtained with regard to artificial feed indicate that the low contents of $\mathrm{AA}$ in the meat of vendace cultured in RAS correspond to the low content of this acid in the formulated feed. There is a view that freshwater fish are capable of converting $\mathrm{C}_{18}$ essential fatty acids (EFA) 18:3n-3 and 18:2n-6 into n-3PUFA and n-6PUFA, in other words, EPA, DHA, and AA (Sargent et al. 1995). The present study indicates that the phenomenon of EFA bioconversion from the $n-6$ family in vendace is either limited or does not occur at all.

From the perspective of the nutritional value of fish meat, it is important to reduce the relative amount of DHA in cultured vendace. The present results differ from those obtained in earlier studies of other freshwater fish species, i.e., pikeperch and wels catfish, in which the application of formulated feed either did not change the percentage share of this acid or resulted in higher levels in comparison to wild individuals of these species that had fed on natural feed (Jankowska et al. 2003, 2007b). It should be noted, however, that because of the significant increase in the content of lipids in vendace from group $\mathrm{C}$, the content of EPA, DHA, n-3 PUFA, and PUFA in $100 \mathrm{~g}$ edible vendace (gutted and headed fish) was significantly higher than that determined in wild individuals of this species.

\section{Summary}

Conducting vendace culture in RAS on high-energy artificially formulated feed produced fish with a slaughter yield for gutted and headed fish did not differ significantly from that of wild fish, but this product contained many times more lipids and a different fatty acid composition than did vendace that had fed on natural food. Cultured vendace was characterized by higher total MUFA and lower PUFA, including n-3 PUFA. However, because of the higher lipid content in the cultured fish, the contents of EPA and DHA and n-3 PUFA and PUFA in 100 g edible vendace (gutted and headed fish) was significantly higher than in wild vendace. It should be emphasized that in the current experiment vendace were cultured on commercial formulated feed that did not fully meet the nutritional requirements of this species. It is possible that applying another type of diet could have a different impact on the proximate composition and the nutritional value of vendace meat.

Acknowledgment. This paper was written as part of statutory project no. S-028 of the Inland Fisheries Institute in Olsztyn and research program no. 528-0704-0806 of the University of Warmia and Mazury. Permission to perform experiments on animals was granted by Local Ethics Committee Resolution no. 24/2011.

Author contributions. Z.Z., R.P.-F., M.S. and M.M.-K. - designed the research, Z.Z., R.P.-F., M.S. and M.M.-K. - performed the research, Z.Z. and R.P-F. - analyzed data, Z.Z., R.P.-F. and M.M.-K. - wrote the paper.

ORCID ID

Zdzisław Zakęś. (iD https://orcid.org/0000-0003-3393-5913

\section{References}

Ahlgren G., Blomqvist P., Boberg M., Gustefsson I.-B. 1994 Fatty acid content of the dorsal muscle - an indicator of fat quality in freshwater fish - J. Fish Biol. 45: 131-157.

AOAC 1995 - Official methods of analysis of Association of Official Analytical Chemists (16th ed.). Arlington, USA: Association of Official Analytical Chemists.

Badiola M., Mendiola D., Bostock J. 2012 - Recirculating aquaculture systems (RAS) analysis: main issues on management and future challenges - Aquacult. Eng. 51: 26-35.

Bell J.G., McEvoy J., Tocher D.R., McGhee F., Campbell P.J., Sargent J.R. 2001 - Replacement of fish oil with rapeseed oil in diets of Atlantic salmon (Salmo salar) affects tissue lipid compositions and hepatocyte fatty acid metabolism - J. Nutr. 131: 1535-1543.

Brylińska M. 2000 - Freshwater Fish of Poland Wydawnictwo PWN, Warszawa, Poland (in Polish).

Cejas J.R., Almansa E., Jérez S., Bolańos A., Samper M., Lorenzo A. 2004 - Lipid and fatty acid composition of muscle and liver from wild and captive mature female broodstocks of white seabream, Diplodus sargus - Comp. Biochem. Physiol. B 138: 91-102. 
Cichoń R. 2003 - Lipids in human nutrition - In: Chemical and functional properties of food lipids (Eds) Z.E. Sikorski, A. Kołakowska. CEC Press LLC, New York, USA: 189-204.

Elliott J.A., Bell V.A. 2011 - Predicting the potential long-term influence of climate change on vendace (Coregonus albula) habitat Bassenthwaite Lake, U.K. Freshwat. Biol. 56: 395-405.

FAO 2019a - Global Capture Production 1950-2017. (http://www.fao.org/fishery/statistics/global-captureproduction/query/en) (accessed Sept. 16, 2019)

FAO 2019b - Global Aquaculture Production 1950-2017. (http://www.fao.org/fishery/statistics/globalaquaculture-production/query/en) (accessed Sept. 16, 2019).

Jankowska B., Zakęś Z., Żmijewski T., Szczepkowski M. 2003 - A comparison of selected quality features of the tissue and slaughter yield of wild and cultivated pikeperch (Sander lucioperca (L.)) - Eur. Food Res. Technol. 217: 401-405.

Jankowska B., Zakęś Z., Żmijewski T., Szczepkowski M. 2010 - Fatty acids profile of muscles, liver and mesenteric fat in wild and reared perch (Perca fluviatilis L.) - Food Chem. 118: 764-768.

Jankowska B., Zakęś Z., Żmijewski T., Szczepkowski M., Kowalska A. 2007a - Slaughter yield, proximate composition, and flesh colour of cultivated and wild perch (Perca fluviatlis L.) - Czech J. Anim. Sci. 52: 260-267.

Jankowska B., Zakęś Z., Żmijewski T., Szczepkowski M., Wunderlich K. 2006 - The impact of diet on the slaughter yield, proximate composition, and fatty acids profile of fillets of tench (Tinca tinca (L.)) - Arch. Pol. Fish. 14: 195-211.

Jankowska B., Zakęś Z., Żmijewski T., Ulikowski D., Kowalska A. 2007b - Slaughter value and flesh characteristics of European catfish (Silurus glanis) fed natural and formulated feed under different rearing conditions Eur. Food Res. Technol. 224: 453-459.

Jobling M. 2001 - Nutrient partitioning and the influence of feed composition on body composition - In: Food Intake in Fish (Eds) D. Houlihan, T. Boujard, M. Jobling. Blackwell Science Ltd., Oxford, UK: 354-375.

Lie Ø. 2001 - Flesh quality - the role of nutrition - Aquacult. Res. 32: 341-348.

Linko R.R., Rajasilta M., Hiltunen R. 1992 - Comparison of lipid and fatty acids composition in vendace (Coregonus albula L.) and available plankton feed - Comp. Biochem. Physiol. A 103: 205-212.
Macrae R., Robinson R.K., Sadler M.J. 1993 - Encyclopaedia of Food Science. Food Technology and Nutrition, Academic Press, London, UK.

Mairesse G., Thomas M., Gardeur J.-N., Brun-Bellut J. 2005 - Appearance and technological characteristics in wild and reared Eurasian perch, Perca fluviatilis (L.) Aquaculture 246: 395-311.

Martins C.I.M., Eding E.H., Verdegem M.C.J., Heinsbroek L.T.N., Schneider O., Blancheton J.P., Roque d'Orbcastel E., Verreth J.A.J. 2010 - New developments in recirculating aquaculture systems in Europe: a perspective on environmental sustainability - Aquacult. Eng. 43: 83-93.

Muje P., Ågren J.J., Lindquist O.V., Hänninen O. 1989 Fatty acids composition of vendace (Coregonus albula L.) muscle and its plankton feed - Comp. Biochem. Physiol. B 92: 75-79.

Sargent J.R., Bell J.G., Bell M.V., Henderson R.J., Tocher D.R. 1995 - Requirement criteria for essential fatty acids - J. Appl. Ichthyol. 11: 183-198.

Setälä J., Honkanen A. Vihervuori A., Nylander E., Söderkultalahti P., Tuunainen A.L. 1999 - Review of the fish market in Finland - Boreal Environ. Res. 3: 361-370.

Steffens W. 1997 - Effects of variation in essential fatty acids in fish feeds on nutritive value of freshwater fish for humans - Aquaculture 151: 97-119.

Steffens W., Wirth M. 2005 - Freshwater fish - an important source of n-3 polyunsaturated fatty acids: a review Arch. Pol. Fish. 13: 5-16.

Szczepkowska B., Szczepkowski M., Piotrowska I. 2014 Impact of feed rations on growth, selected body parameters and maturation of vendace, Coregonus albula L., reared in RAS - Arch. Pol. Fish. 22: 145-150.

Watanabe T. 2002 - Strategies for further development of aquatic feeds - Fish. Sci. 68: 242-252.

Woźniak M., Poczyczyński P., Kozłowski K. 2013 - The nutritional value of selected species of fish from lake and fish farm of north-eastern Poland - Pol. J. Natur. Sci. 28: 295-304.

Wziątek B., Kozłowski J., Teodorowicz M., Kurenda P. 2009 Effects of producing stocking material of vendace Coregonus albula (L.), using spawners reared in captivity - initial studies - Arch. Pol. Fish. 17: 99-102.

Xu X.L., Fontaine P., Mélard C., Kestemont P. 2001 - Effects of dietary fat levels on growth, feed efficiency and biochemical composition of Eurasian perch Perca fluviatlis Aquacult. Int. 9: 437-449. 